\title{
Separation effects in a microregion: traffic volume estimation between the settlements of Lake Velence
}

\author{
Zsombor Szabó In an analysis of separation effects, borders \\ Budapest University of Technology are usually taken into consideration. \\ and Economics, Hungary However, in addition to country borders, \\ E-mail: borders within a microregion that are \\ szabo.zsombor@mail.bme.hu experiencing resistance, for example, county \\ borders, may also exhibit separation effects. \\ Tibor Sipos \\ Budapest University of Technology \\ and Economics, Hungary \\ E-mail: sipos.tibor@mail.bme.hu \\ Keywords: \\ separation effect, \\ gravity modelling, \\ spatial statistics, \\ In this article the focus is on such borders; a \\ separation effect has been proven in the \\ microregion of Lake Velence and its \\ surroundings (in Hungary). The novelty of \\ the analysis is that the effect of the order of \\ settlements is taken into consideration as \\ proof of its usability. In doing so, a more \\ accurate gravitational model can be built for \\ modelling the number of commuters in the \\ microregion, which, in turn, can be used to \\ predict traffic demand. \\ transportation geography
}

\section{Introduction}

In transportation sciences the effect of spatial separation on transportation is researched occasionally and usually focuses on national borders. However, county and district borders also exhibit a separation effect. This can be analysed through changes in the transport demand. However, there are several aspects to the demand for transportation (work, school, leisure). This article only considers daily commuting or commuter travel demand. It should be noted that although recreational travel is also significant, here it is outside the scope of the investigation.

It is widely acknowledged that the strictness of borders influences traffic volumes. For instance, free trade agreements between Indonesia and Malaysia, which include facilitating border crossing, can significantly improve the quality of road freight transport between the two countries (Opasanon-Kitthamkesorn 2016). Numerous studies analyse the relationship between the United States and Canada. Authors (Avetisyan et al. 2015) show how the use of one additional border guard affects the development of a given border crossing and bilateral relations. However, several authors (Bradbury 2013, Brown-Anderson 2015, Burt 2009, Maoh et al. 2016, Park et al. 2014) estimate traffic volume and bilateral relations based on

Regional Statistics, Vol. 10. No. 2. 2020:186-205; DOI: 10.15196/RS100208 
economic performance and the strictness (resistance) of border surveillance. The effects have been demonstrated in the European region (Miltiadou et al. 2017), and the results discussed the impact of cross-border isolation in the rest of the European Union (EU) on Greece. A situation similar to that of Hungary is presented in an article (Niebuhr 2008) on how reducing the cost of cross-border movement influences the condition of individual border regions. The relationship between cross-border traffic and the micro-environment of border crossing points has also been described (Szabó et al. 2017, Szabó-Török 2018a, b). The findings indicate that resistance to cross-border traffic (such as the Schengen Convention or EU membership) has a significant impact on traffic volume.

In Hungary, numerous transport features were surveyed during the 2011 census. For example, daily commuters were asked about their origin and destination according to the different transportation modes (KSH 2011). As the publication of low values would violate privacy in many cases, only an excerpt of this survey is publicly available, which shows the extent of commuting to district centres by any means of transportation. Based upon these data, using spatial statistic tools, in particular the gravity model, it is possible to produce the origin-destination (OD) matrix for describing traffic flows between the settlements (Dusek-Kotosz 2016).

The gravity model is often used in numerous fields of science (e.g. Márkus 2018) as well as in transport sciences in order to determine the estimated traffic demand between two points in space. It was first used for transportation research by John Q. Stewart (1948) in a article; however, in the case of railways the usefulness of the gravity model usage in 1846 is proven (Odlyzko 2015). Efforts have been made to analyse the impact of geographical features on international trade (Limão-Venables 2001). The relationship and the volume of transport between countries can be examined based on the similar properties of the neighbours (e.g. similar language, closeness or whether is there a border between them) using a gravity model (Hummels 1999).

The purpose of this paper is to refine gravity models by considering other spatial effects. Our goal is to illustrate the order of settlements through theoretical models, and the separation effects - based upon (McCallum 1995) - through a practical example, and to estimate current traffic demand. To this end, in the second section, we present the methodology, including the characteristics of the area and the explanatory variables. In the third section, the results of each model are presented, while the fourth section shows an evaluation of the main parameters.

Regional Statistics, Vol. 10. No. 2. 2020:186-205; DOI: 10.15196/RS100208 


\section{Methodology}

During the analysis, the wider environment of Lake Velence in Hungary was taken into consideration. The test site included the Gárdony District and parts of the related districts of Bicske, Martonvásár, Dunaújváros, Székesfehérvár, and the national capital (Rechnitzer et al. 2019, Varga et al. 2020). The site was chosen because it satisfies multiple criteria: first, the area has recently been experiencing a demand to upgrade the transportation network. The next criterion was the existence of a quasi-closed bus network - a compact network comprising a few main lines and some connecting lines, thus minimising the number of lines leading out of the network. Furthermore, the separation effect can be observed, and during the reform of the LAU-1 level of administration in Hungary, the borders were changed, so change in transportation flows can be observed.

In terms of the regional bus network, there are three main routes from Székesfehérvár toward the chosen region, specifically, in the direction of Bicske (via Lovasberény on road nr. 811), Kápolnásnyék (via Sukoró on road nr. 8116), and Martonvásár (via Gárdony on road nr. 7). The most important bus links use these three routes. There are also some lines connecting the three main routes, for example, Bicske-Martonvásár (via Vál on road nr. 8111) and Lovasberény-Velence (via Vereb on road nr. 8117). There are two joined lines between VelencePusztaszabolcs and Gárdony-Zichyújfalu-Szabadegyháza. These links create a compact network with connection points on three railway lines in Bicske, Székesfehérvár, Kápolnásnyék, and Pusztaszabolcs, and important bus routes in Szabadegyháza and Bicske. There are only three bus lines that connect unmentioned settlements and create fulfill outside the region (Bicske-Etyek, Etyek-Tabajd, and Besnyó-Pusztaszabolcs-Adony); however, there is only one bus service per day. A map of the region is presented in Figure 1. 


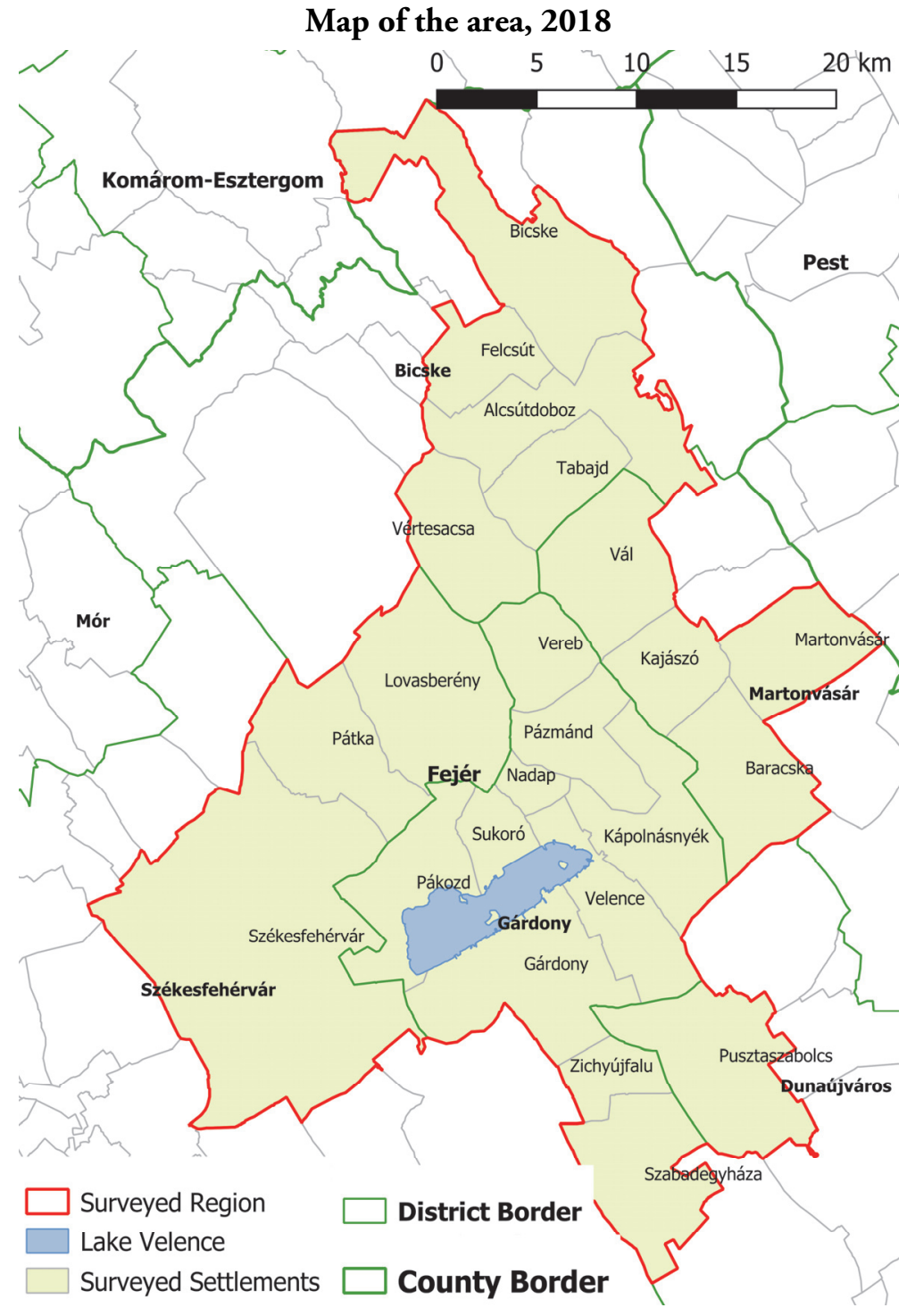

In this case the gravity model will serve to estimate the amount of traffic demand between two settlements. To this end, first the 2011 parameter values are estimated from the available data (using the 2011 data) and then, assuming they are independent of time, these are applied to the 2018 data set. Baseline data is the commuter traffic that can be extracted from the 2011 official census data (Table 1). The columns show the departure settlements, while the destination cities are reported in the rows.

Regional Statistics, Vol. 10. No. 2. 2020:186-205; DOI: 10.15196/RS100208 
Table 1

The available data for commuting (commuters per day) in the analysed area, 2011

\begin{tabular}{|c|c|c|c|c|c|}
\hline From To & Budapest & Székesfehérvár & Bicske & Gárdony & Martonvásár \\
\hline Budapest & - & 624 & 200 & 32 & 64 \\
\hline Székesfehérvár & 1893 & - & 33 & 156 & 38 \\
\hline Alcsútdoboz & 78 & 11 & 91 & 1 & 1 \\
\hline Baracska & 358 & 45 & 77 & 27 & 6 \\
\hline Bicske & 830 & 30 & - & 1 & 2 \\
\hline Felcsút & 114 & 11 & 146 & 1 & 1 \\
\hline Gárdony & 515 & 925 & 1 & - & 28 \\
\hline Kajászó & 136 & 19 & 9 & 4 & 13 \\
\hline Kápolnásnyék & 280 & 198 & 1 & 56 & 15 \\
\hline Lovasberény & 31 & 494 & 33 & 9 & 2 \\
\hline Martonvásár & 716 & 72 & 8 & 8 & - \\
\hline Nadap & 45 & 37 & 1 & 9 & 1 \\
\hline Pákozd & 58 & 728 & 1 & 14 & 1 \\
\hline Pátka & 18 & 466 & 2 & 1 & 1 \\
\hline Pázmánd & 168 & 83 & 2 & 20 & 14 \\
\hline Pusztaszabolcs & 517 & 186 & 1 & 13 & 4 \\
\hline Sukoró & 90 & 172 & 1 & 8 & 2 \\
\hline Szabadegyháza & 14 & 336 & 1 & 7 & 1 \\
\hline Tabajd & 40 & 5 & 88 & 0 & 2 \\
\hline Vál & 259 & 19 & 69 & 1 & 29 \\
\hline Velence & 409 & 310 & 2 & 94 & 10 \\
\hline Vereb & 34 & 51 & 2 & 8 & 2 \\
\hline Vértesacsa & 30 & 162 & 58 & 0 & 1 \\
\hline Zichyújfalu & 8 & 148 & 2 & 46 & 3 \\
\hline
\end{tabular}

Source: authors based on the KSH (2011) survey.

The gravity model is based on Newton's law of universal gravitation (1).

$$
F=-\gamma \frac{m_{1} m_{2}}{\mathrm{r}^{3}} r
$$

where: $F$ : is the gravitational force acting between two objects; $m_{1}, m_{2}$ : are the masses of the objects; $r$ is the distance vector between the centres of their masses $(r$ is the scalar value); $\gamma$ is the gravitational constant.

Note that the exponent of the $r$ is 3 instead of 2, owing to the vectorial form. The scalar form of Eq. 1 can be transformed to calculate the transportation demand (denoted by $\mathrm{U}$ ) between two settlements (Eq. 2).

$$
U=\gamma \frac{m_{1} m_{2}}{r^{2}}=\gamma m_{1} m_{2} r^{-2}
$$


To accomplish the analysis, it is necessary to estimate the parameters of the gravity model. There are two possible methods for setting the model parameters. One is when the exponent of the distance is considered to be constant and known, so only $\gamma$ needs to be estimated (Jung et al. 2008). In this case, simple linear regression can be applied without a constant term. However, this analysis uses another approach wherein, besides $\gamma$, the exponent of the distance and the exponent of the settlement populations are also estimated (Okubo 2004). While using the power function on population is not the most effective in terms of the model's reality, there are many examples of weighting the population by some factor to better estimate mobility propensity (Dusek-Kotosz 2016). Thus, a linear regression model is used that contains logarithmic dependent and explanatory variables.

The explanatory variables of the models can be divided into two groups. One is a group of variables derived from the classical gravity model (CGM), which includes the population of the settlements (KSH 2018) and the distance between settlements. In terms of population, two models can be set up. In one case, the explanatory variable is going to be the product of the population of the two settlements, while in the other the weighting of the population is done separately.

In all cases the distance is the time needed for commuting (assuming an arrival time no later than 8:30 am), based on the timetable data (Saif et al. 2018). The reason behind this is that the public transportation network holds a significant role in case of daily commuting (Lakatos et al. 2020, Lakatos-Mándoki 2020, Pupavac et al. 2019). In the case of distance calculating there is a debate about methods that can or cannot be used (Dusek 2011, Nagy 2011), however the timetable data seems to be acceptable. The transportation network or infrastructure distance is widely used in different researches, for example (Pálóczi 2016, Pálóczi et al. 2016, Kincses et al. 2016, Varga et al. 2016, Guzik et al. 2017, Kiss-Szalkai 2018, Tagai et al. 2018, Mátyás et al. 2019).

Examining the previous table and summarising the number of commuters reveals that on one hand, traffic demands are not symmetrical (since more people commute from the smaller settlements to the populated ones) (KoneckaSzydłowska et al. 2019, Novotný-Pregi 2019, Alpek-Tésits 2019, Molnár et al. 2018), and traffic operates on two levels (regional, national). Therefore, the introduction of additional explanatory variables for the extended gravity models (EGM), which belong to the other group of variables is recommended. The first is the rate of the orders, denoted by $C_{B}$. The order is a number between 0 and 5 assigned to each settlement based on the European Union's NUTS (Nomenclature des Unités Territoriales Statistiques - Nomenclature of Territorial Units for Statistics) (Brandmueller et al. 2017). $C_{B}$ compares the order of the two settlements between which commuting occurs (Szabó et al. 2019). In the case of Hungary, Budapest's order is 0 , as it is the capital. The NUTS-1 and NUTS-2 levels are only statistical, so no settlement is assigned to this level. The county towns (for example,

Regional Statistics, Vol. 10. No. 2. 2020:186-205; DOI: 10.15196/RS100208 
Székesfehérvár) are denoted by 3, while district seats (for example, Gárdony) are denoted by 4 . The remaining settlements are in order 5 . Based on these values, a ratio can be calculated for the settlement pairs as follows (Eq. 3).

$$
c_{B}=\frac{c_{\text {from_settlement }}}{c_{\text {to_settlement }}}
$$

where $C$ is always the actual order of the settlement.

However, it is worth noting that some modifications in the definition of the order were needed here, since the logarithm of the coefficients needs to be determined later, and consequently, none of the coefficients can be 0 . Therefore, the order of Budapest is set to 1 in further calculations. Another change to the previously introduced rules is that due to the characteristics of the micro-region, it is worth considering Agárd and Dinnyés as separate settlements. However, these are officially part of the town of Gárdony, so their order will be 6 .

The differences in the borders in Fejér County, 2018

Figure 2

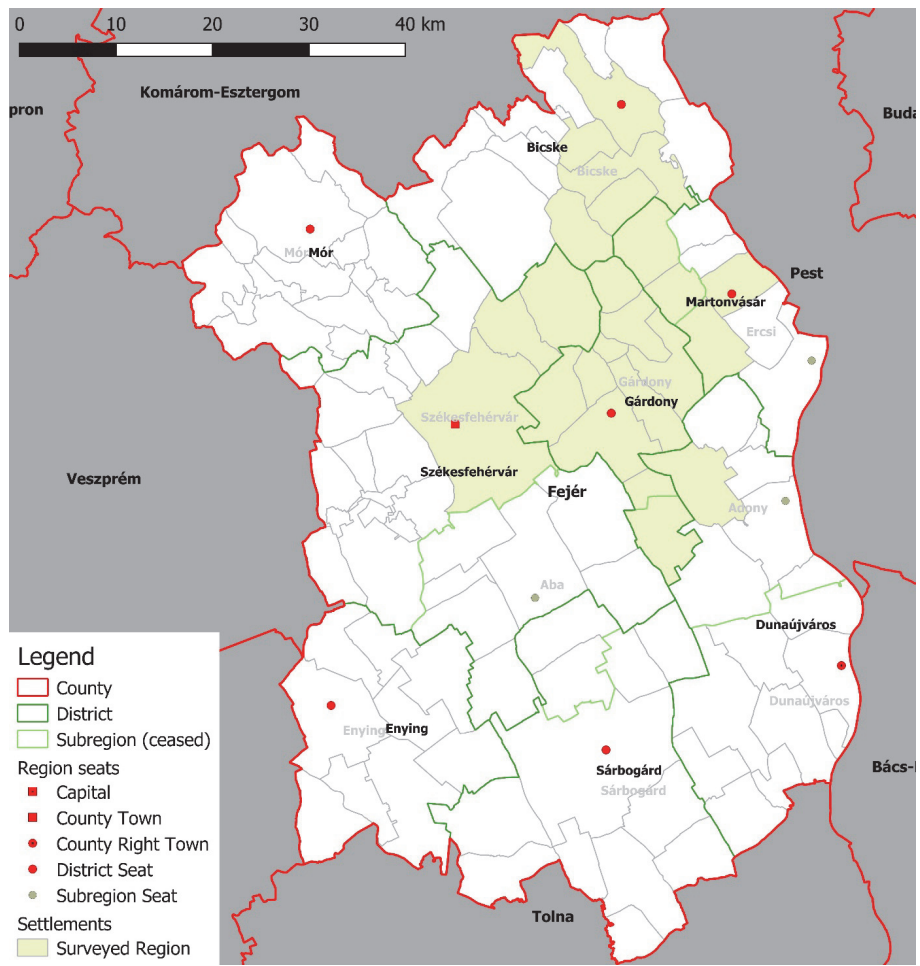

Two additional explanatory variables were introduced to model the difference between regional and national traffic. $j$ indicates the number of the districts affected, while $h$ indicates the number of counties concerned. It must be noted that in 2013

Regional Statistics, Vol. 10. No. 2. 2020:186-205; DOI: 10.15196/RS100208 
there was a reform of the LAU-1 administration level in Hungary. Before 2013, and in 2011, the districts were called kisterség - 'subregion' in Hungarian. After 2013, the LAU-1 units were renamed járás in Hungarian, for which the district will be used. It was not only a change in terminology; the borders were modified as well, so this should be taken into consideration at different levels of modelling. Thus, when the parameters are estimated for the models, $j$ stands for the pre-2013 administration; and when the OD matrix is estimated, the post-2013 system will be taken into consideration. The difference is shown in the map of Figure 2.

Based on the introduction of the variables, two extended models could be set up, which will be compared to CGM. In the first model population data are treated together, so they are multiplied before the modelling (extended gravity modelmultiplied before modelling or EGM-MBM). In the second model (based on Okubo (2004)), the two population variables are multiplied after parameter estimation (Extended gravity model-multiplied after modelling or EGM-MAM). Therefore, the following linear regression model EGM-MBM can be constructed by treating the product of the settlement population as a unit.

$$
\ln U=\alpha+\beta_{1} \ln \left(m_{1} m_{2}\right)+\beta_{2} \ln r+\beta_{3} \ln c_{B}+\beta_{4} \ln j+\beta_{5} \ln h
$$

where: $U$ : number of commuters for a given pair of settlements in a given direction; $a$ : constant; $\beta_{\mathrm{i}}$ : estimated parameter of the explanatory variables; $m_{1}, m_{2}$ : population of the settlements; $r$ : the distance between settlements; $C_{B}$ : the ratio of the orders defined by the settlement relationships; $j$ : number of districts; $b$ : number of counties.

If the exponentiation of Eq. 4 is taken, a formula similar to Eq. 2 arises (Eq. 5).

$$
U=e^{\alpha}\left(m_{1} m_{2}\right)^{\beta_{1}} r^{\beta_{2}} c_{B}^{\beta_{3}} j^{\beta_{4}} h^{\beta_{5}}
$$

In this case, the $\gamma$ from Eq. 2., originally the gravitational constant, is described by Eq. 6 .

$$
\gamma=e^{\alpha} c_{B}^{\beta_{3}} j^{\beta_{4}} h^{\beta_{5}}
$$

As previously mentioned, two models could be set up, the first is described by Eq. 4, while the second (EGM-MAM) is described by Eq. 7.

$$
\ln U=\alpha+\beta_{1} \ln m_{1}+\beta_{2} \ln m_{2}+\beta_{3} \ln r+\beta_{4} \ln c_{B}+\beta_{5} \ln j+\beta_{6} \ln h
$$

Based on the aforementioned models, two main steps in the analysis can be defined. The first is to determine the $\beta$ coefficients for each model. This proves that county boundaries and district boundaries exercise a separation effect, which is an obstacle for daily commuting. The second is to determine the traffic demand between settlements using 2018 data, assuming the constancy of coefficients. In this way, it can be seen how the dynamic change of the population (as we can talk about the suburbs of Budapest) and the change in the LAU-1 administration influenced traffic volumes; however, this falls outside the scope of this article. In addition, the full OD matrix can be estimated, instead of commuting only to district centres, which can be used in further analysis.

Regional Statistics, Vol. 10. No. 2. 2020:186-205; DOI: 10.15196/RS100208 


\section{Results}

\section{CGM}

The results for the linear regression of the CGM are shown in Table 2. Hybrid, Fisher, and Newton-Raphson methods (Ketskeméty et al. 2011) were used alternately in parameter estimation. The number of iterations was usually set to 200 , and the convergence criterion for the iterations was linked to a minimum change of $1 \mathrm{E}-006$ in the parameter estimates. In each case, Type III model effect analysis was used, as it is the default, choosing Wald Chi-square statistics and confidence intervals. The confidence interval was set to $95 \%$. The rows in the table include the coefficient for each variable and the associated $t$-value (in square brackets). The significance level of the $t$-values is denoted alongside: if $p<0.1, *$ if $p<0.05$, ** if $p<0.01$, and $* * *$ if $p<0.001$.

Table 2

\section{Parameters of the linear regression model, 2011}

\begin{tabular}{l|c}
\hline \multirow{2}{*}{ Intercept } & 2.3328 \\
\cline { 2 - 2 } & {$[2.0698]^{*}$} \\
\hline \multirow{2}{*}{$\ln m_{1}$} & 0.3855 \\
\hline \multirow{2}{*}{$\ln m_{2}$} & {$[6.2518]^{* * *}$} \\
\hline \multirow{2}{*}{$\ln r$} & 0.7801 \\
\hline R 2 & {$[16.4673]^{* * *}$} \\
\hline Standard Error & -2.6212 \\
\hline F-statistics & {$[-11.2459]^{* * *}$} \\
\hline
\end{tabular}

Based on the results, it can be seen that in case of CGM, the $R^{2}$ value is smaller than in the case of extended models. The other difference is the greater exponent (note that only in absolute value) of the distance parameter. These results can be compared to the two extended models below.

\section{EGM-MBM}

In the case of EGM-MBM, as aforementioned, the multiplication of the population parameters is made before the parameter estimation, so these are treated jointly. The results of the parameter estimation are in Table 3 . The legend is the same as for Table 2.

Regional Statistics, Vol. 10. No. 2. 2020:186-205; DOI: 10.15196/RS100208 
Parameters of the linear regression model, 2011

\begin{tabular}{|c|c|}
\hline \multirow{2}{*}{ Intercept } & 3.9847 \\
\hline & {$[2.4811]^{*}$} \\
\hline \multirow{2}{*}{$\ln m_{1} m_{2}$} & 0.8598 \\
\hline & {$[12.8762]^{* * *}$} \\
\hline \multirow{2}{*}{$\ln r$} & 1.9787 \\
\hline & {$[8.0645]^{* * *}$} \\
\hline \multirow{2}{*}{$\ln c$} & 0.9401 \\
\hline & {$[5.6546]^{* * *}$} \\
\hline \multirow{2}{*}{$\ln j$} & -1.3894 \\
\hline & {$[-3.9133]^{* * *}$} \\
\hline \multirow{2}{*}{$\ln b$} & -1.9247 \\
\hline & {$[-3.0264]^{* *}$} \\
\hline $\mathrm{R}^{2}$ & 0.8079 \\
\hline Standard Error & 0.9449 \\
\hline F-statistics & {$[91.7085]^{* * *}$} \\
\hline
\end{tabular}

According to the Gauss-Markov theorem, an estimate can be considered as the best linear unbiased estimate (BLUE) if the conditions of the classical linear model are met, among which the condition that distribution of the error terms must be normal (Bolla-Krámli 2005). For this, we used the Kolmogorov-Smirnov test (Massey 1951), applying a distance from a theoretical normal distribution at both ends of the interval. The value of the test statistic can be determined by Eq. 8 (Ketskeméty et al. 2011):

$$
D_{n}=\sqrt{n} \sup _{x \in R} F_{n}(x)-F_{0}(x) \mid
$$

where: $D$ n: the value of the test statistics; $n$ : sample size; $F_{0}(x)$ : theoretical cumulative distribution function; $F_{\mathrm{n}}(x)$ : sample cumulative distribution function. If $D \mathrm{n}<K s$, then the null hypothesis, which is that the distribution of the sample is the same as the theoretical distribution, is accepted. The critical values for the test statistics are listed in Table 4 (Ketskeméty et al. 2011).

\section{The critical values for the test statistics}

Table 4

\begin{tabular}{l|l}
\hline \multicolumn{1}{c|}{$\varepsilon$} & $K(\varepsilon)$ \\
\hline 0.9 & 1.23 \\
0.95 & 1.36 \\
0.99 & 1.63 \\
0.999 & 1.96 \\
\hline
\end{tabular}

Source: authors, based on Ketskeméty et al. (2011).

Since in this case the value of the test statistic $\left(D_{\mathrm{n}}=1.1609\right)$ is less than the critical value $K(\varepsilon)$ of 0.9 , the null hypothesis that the error vector is normally distributed is acceptable. Based on these factors, the traffic demand between individual settlements can be estimated (Table 5).

Regional Statistics, Vol. 10. No. 2. 2020:186-205; DOI: 10.15196/RS100208 


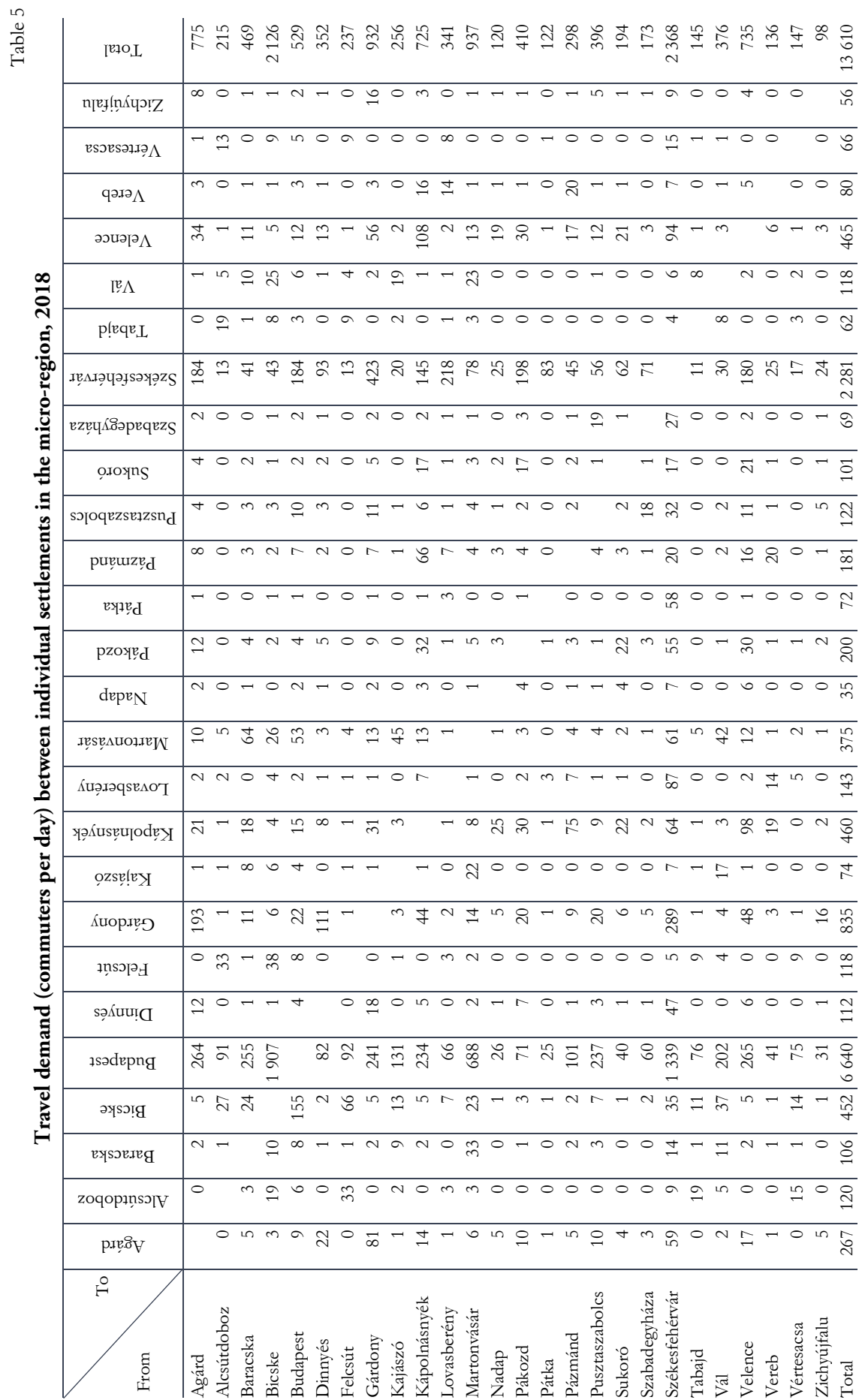

Regional Statistics, Vol. 10. No. 2. 2020:186-205; DOI: 10.15196/RS100208 


\section{EGM-MAM}

As mentioned in the other model, the population of the settlements is weighted separately according to whether it is an origin or a destination. The parameter table of the linear regression model is illustrated in Table 6 . The legend is the same as for Table 2.

Table 6

Parameters of the linear regression model, 2011

\begin{tabular}{l|c}
\hline \multirow{2}{*}{ Intercept } & 5.1249 \\
\cline { 2 - 2 } & {$[-3.2970]^{*}$} \\
\hline \multirow{2}{*}{$\ln m_{1}$} & 0.5372 \\
\hline \multirow{2}{*}{$\ln m_{2}$} & {$[4.9362]^{* * *}$} \\
\cline { 2 - 2 } $\ln r$ & {$[.2872$} \\
\hline \multirow{2}{*}{$\ln c$} & $-2.0573]^{* * *}$ \\
\hline \multirow{2}{*}{$\ln j$} & {$[-8.6816]^{* * *}$} \\
\hline \multirow{2}{*}{$\ln b$} & -0.5910 \\
\hline \multirow{2}{*}{$\mathrm{R}^{2}$} & {$[-1.3170]$} \\
\hline Standard Error & -1.3588 \\
\hline F-statistics & {$[-4.0356]^{* * *}$} \\
\cline { 2 - 2 } & -1.8762 \\
\hline
\end{tabular}

The Kolmogorov-Smirnov Test statistics $\left(D_{\mathrm{n}}=1.0486\right)$ is still lower than the critical value $K(\varepsilon)$ of 0.9 , so the null hypothesis is also acceptable in this case (Ketskeméty et al. 2011). On this basis, the estimated commuter travel demand between different settlements can be determined (Table 7). 


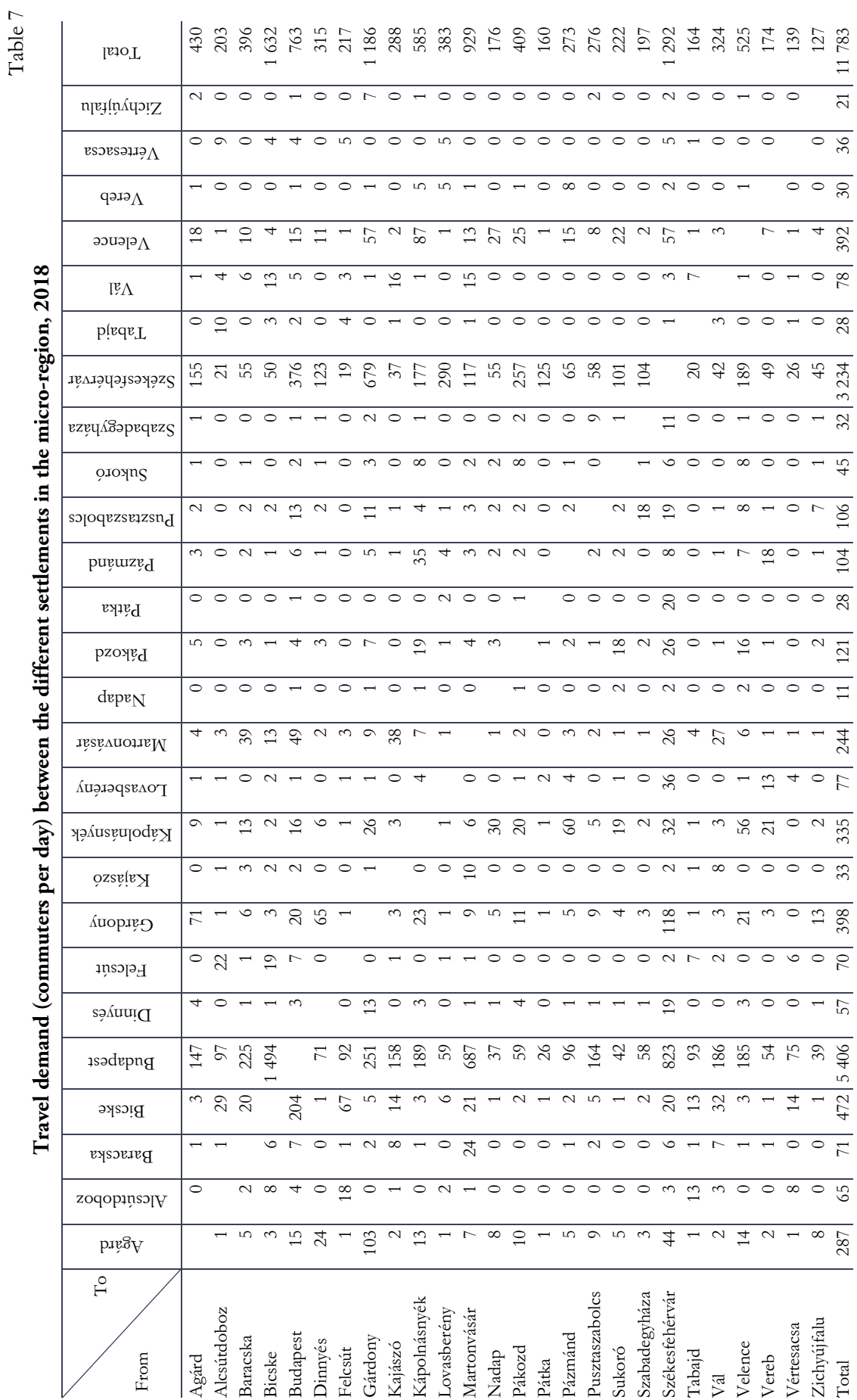

Regional Statistics, Vol. 10. No. 2. 2020:186-205; DOI: 10.15196/RS100208 
A comparison of the two matrices shows that the models estimate different demands in many relations. It is worth examining the individual coefficients to determine the causes of these effects. Beta coefficient is often used in statistics to compare the explanatory power of parameters. Calculation is possible with the formula of Eq. 9, while the explanatory strengths thus obtained are illustrated in the diagram of Figure 3 (Ketskeméty et al. 2011).

$$
B E T A_{i}=b_{i} \frac{\sigma_{x_{i}}}{\sigma_{z}} \forall i \in[1 . . n]
$$

where: $B E T A_{\mathrm{i}}$ : is the beta coefficient for the $i^{\text {th }}$ explanatory variable; $b_{\mathrm{i}}$ : is the estimated parameter for the $i^{\text {th }}$ explanatory variable; $\sigma_{\mathrm{xi}}$ is the variance of the $i^{\text {th }}$ explanatory variable; $\sigma_{\mathrm{y}}$ : is the variance of the dependent variable; $n$ : is the number of explanatory variables.

Figure 3

Beta coefficients for each model and explanatory variables, 2011

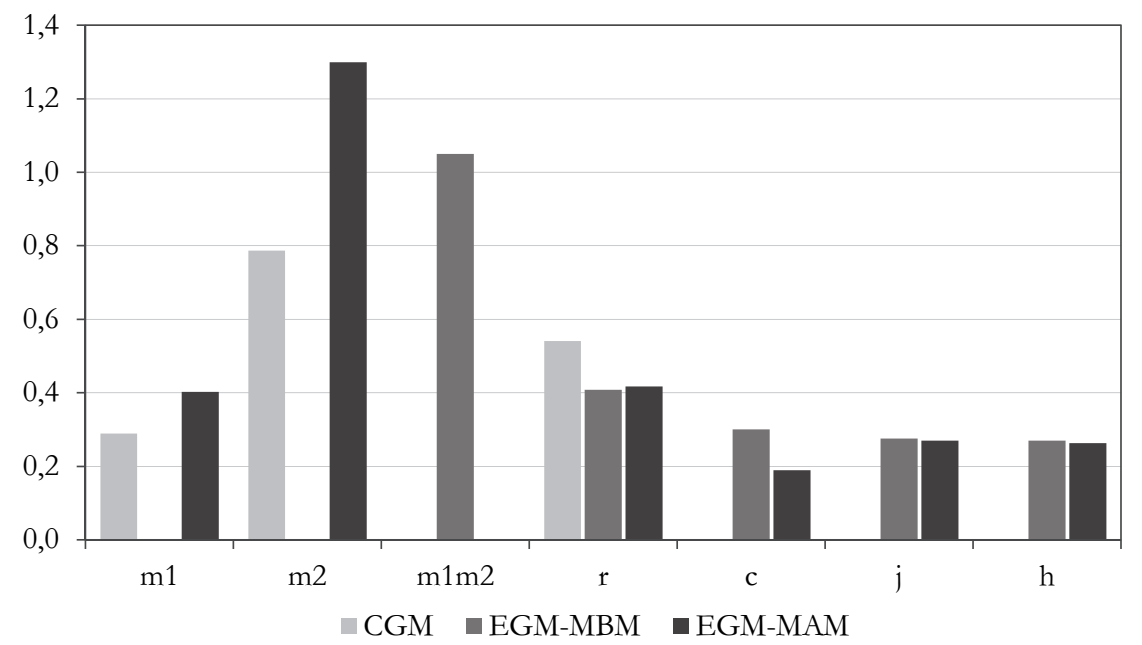

If the beta coefficients are analysed for the models (Figure 3), it can be seen that in the case of CGM, the revelation of the population data is lower than the extended models, while the revelation of the distance is higher. For both extended models, population data are most influential on the outcomes of the calculations. Consequently it is worth examining how population numbers influence model output. This is illustrated in Figure 4, where the two horizontal axes represent the two population numbers, while the vertical axis represents the value of the calculated subtotals.

Regional Statistics, Vol. 10. No. 2. 2020:186-205; DOI: 10.15196/RS100208 
The effect of population data, 2018

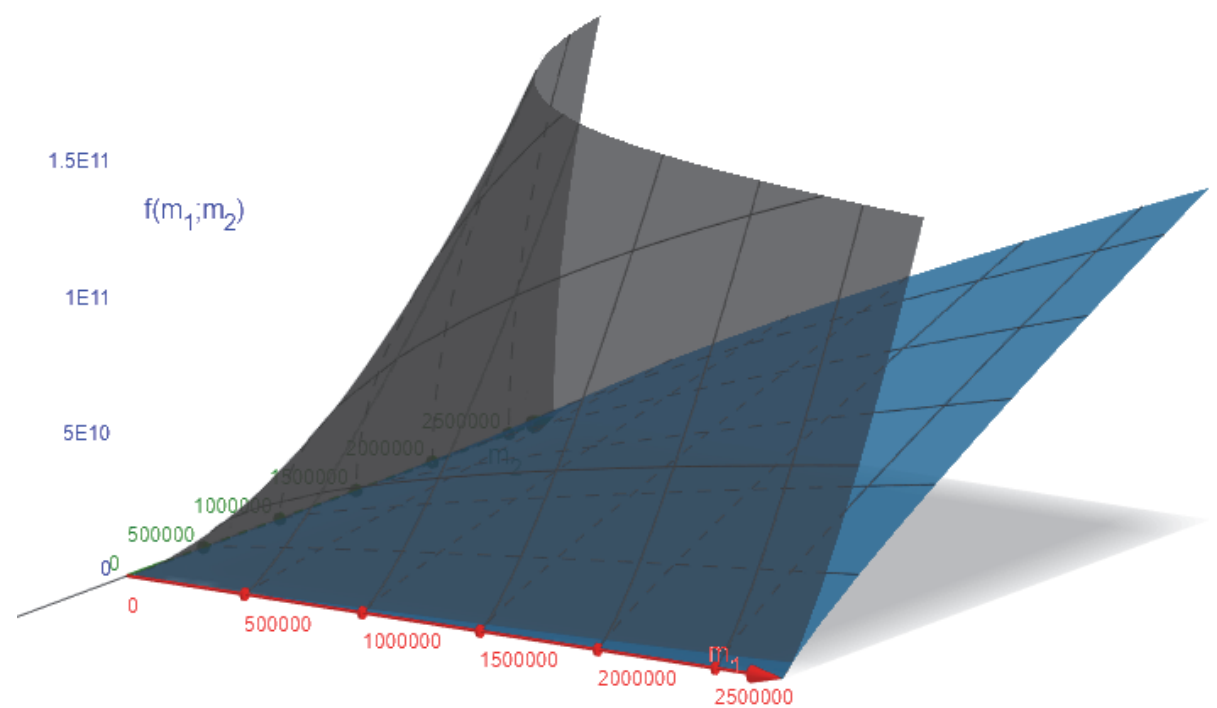

As shown in Figure 4, in the case of settlements with a small population (practically all, except Székesfehérvár and Budapest), differences in the population do not matter, so the other parameters influence model estimates.

If comparing the models is desirable according to which model is better, Table 8 can be taken into consideration. This contains the Omnibus Test and the information criteria associated with the likelihood function. The Omnibus Test is very similar to the $F$-test, the only difference being that here the null hypothesis that the parameters of the explanatory variables do not have all-zero value is tested by the $x^{2}$ test. As seen from the table, both models are suitable based on this approach. The different information criteria calculations (Akaike (AIC, AICC), Bayes (BIC), and Consistent Akaike (CAIC)) are based on Cameron and Trivedi (2005).

Table 8

Parameters for comparing the models, 2011

\begin{tabular}{l|c|c|c}
\hline & CGM & EGM-MBM & EGM-MAM \\
\hline Omnibus & $167.731^{* * *}$ & $189.746^{* * *}$ & $203.082^{* * *}$ \\
Log Likelihood & -164.769 & -153.581 & -146.913 \\
AIC & 339.537 & 321.162 & 309.827 \\
AICC & 340.088 & 322.209 & 311.185 \\
BIC & 353.262 & 340.377 & 331.786 \\
CAIC & 358.262 & 347.377 & 339.786
\end{tabular}

Regional Statistics, Vol. 10. No. 2. 2020:186-205; DOI: 10.15196/RS100208 
In terms of information criteria, the lower they are, the better the model. Table 8 shows that the second model can be considered to be better according to each information criterion. It can thus be concluded that although the order is suitable for modelling commuting relationships, using population figures provides a better model in all respects. Therefore, the use of order is negligible, because its effect is not significant.

\section{Evaluation}

The aim of this study is to present the hypothetical separation effect and the effects of the order of settlements through a practical model. Our analysis proved that in both models the sign and the magnitude of the coefficients of separation effects are adequate. On one hand, it was a pre-requisite for the coefficients to be negative, and on the other, for the county borders to be more significant than the district borders. The results show that both criteria are met. This suggests that administrative borders also have a distorting effect on transport volumes.

As for the county border's separation effect, the only settlement out of Fejér County in the analysed area is Budapest, which could mean that the measured separation effect is due to the special properties of Budapest, the capital of Hungary. However, in gravity modelling, most of its special properties (such as higher distance or population) are separated from the county border effect. Therefore, the hypothesis of the county borders' separation effect could be accepted. This is untrue in the case of districts because more district seats (Bicske, Gárdony, Martonvásár, and Székesfehérvár) were taken into consideration.

In the case of the quotient of orders, the basic idea was that the ratio would be higher when travelling from a smaller settlement to a larger one. As this direction is more significant than the opposite one in our basic hypothesis, the expected sign of the coefficient is positive. In EGM-MBM, the sign of the coefficient was the expected one, however, in EGM-MAM the parameter was no longer significant. This is due to the fact that the role of order ratio here has been taken over by the ratio of population numbers, so the order has become insignificant.

\section{Conclusion}

In this model the travel needs (OD matrix) of the larger area of Lake Velence were determined. To this end, we used a gravity model to which we added the effects of orders and district borders. The first step was based on the known commuting numbers, and as a result, the parameters of the gravity model were estimated. The second step was that assuming the robustness of the parameters, an OD matrix was set up for all the settlements in the surveyed region. For this, two extended gravity models were used and compared to the classic gravity model. It is given that the

Regional Statistics, Vol. 10. No. 2. 2020:186-205; DOI: 10.15196/RS100208 
extended models seem to outperform the classic model based on the information criteria. In the case of the extended models two important independent variables were analysed.

In all, the separation effect is significant in both models and has the appropriate sign, while the effect of rank numbers is significant only in the EGM-MBM. This is because in the second model separately managed populations reduce the explanatory value of order.

In this article, we built a gravity model where the accuracy of commuter travel demand prediction has been improved, and a more accurate OD matrix has been set up. The increase in efficiency is due to the fact that many new explanatory variables have been taken into account in model building. On one hand, we have demonstrated that the county border and the district border have a significant effect on commuter travel demand, and on the other, the possibility to use the orders is also proven. This can be used to further refine the existing traffic generation models.

\section{REFERENCES}

ALPEK, B. L. -TÉSITS, R. (2019): A foglalkoztathatóság mérési lehetôségei és térszerkezete Magyarországon Területi Statisztike 59 (2): 164-187. https://doi.org/10.15196/TS590203

Avetisyan, M.-Heatwole, N.-Rose，A.-Roberts，B. (2015): Competitiveness and macroeconomic impacts of reduced wait times at U.S. land freight border crossings Transportation Research Part A: Policy and Practice 78: 84-101. https://doi.org/10.1016/j.tra.2015.04.027

BOLLA, M.-KRÁMLI, A. (2005): Statisz̨itkai követkę̧tetések elmélete 2nd ed. TYPOTEX Kiadó, Budapest.

BRADBURY, S. L. (2013): The impact of security on travelers across the Canada-US border. Journal of Transport Geography 26, 139-146. https://doi.org/10.1016/j.jtrangeo.2012.08.009

Brandmueller, T-Schäfer, G.-EKKEHARD, P.-MÜller, O.-AngElOVA-TOSHEVA, V. (2017): Territorial indicators for policy purposes: NUTS regions and beyond Regional Statistics 7 (1):78-89. https://doi.org/10.15196/RS07105

Brown, M. W.-Anderson, W. P. (2015): How thick is the border: the relative cost of Canadian domestic and cross-border truck-borne trade, 2004-2009 Journal of Transport Geography 42: 10-21. https://doi.org/10.1016/j.jtrangeo.2014.10.006

BurT, M. (2009): Tighter Border Security and Its Effect on Canadian Exports. Canadian Public Policy/Analyse de Politiques 35, 149-169.

Cameron, A. C.-Trivedi, P. K. (2005): Microeconometrics: Methods and Applications Cambridge University Press, New York.

DuSEK, T. (2011): Inadekvát adatok és egyéb módszertani kérdések a gravitációs modell alkalmazása során Területi Statisztikea 51 (6): 674-677.

DuseK, T.-Kotosz, B. (2016): Terïleti statiştikea Akadémiai Kiadó, Budapest.

Regional Statistics, Vol. 10. No. 2. 2020:186-205; DOI: 10.15196/RS100208 
GuZIK, R.- Kołoś, A.-GwOsDZ, K. (2017): Interconnections in public transport as a method for delimiting urban functional areas and the settlement hierarchy in Poland Regional Statistics 7 (1): 63-77. https://doi.org/10.15196/RS07104

HuMMELS, D. L. (1999): Toward a geography of trade costs SSRN Electronic Journal 30. https://doi.org/10.2139/ssrn.160533

Jung, W.-S.-WANG, F.-STANLEY, H. E. (2008): Gravity model in the Korean highway EPL (Europhysics Letters) 81: 48005. https://doi.org/10.1209/0295-5075/81/48005

KeTSKEMÉTY, L.-IzSÓ, L.-KÖNYVES TóTH, E. (2011): Bevezetés az IBM SPSS Statistics programrendszerbe 3. kiad. ed. Artéria Studió, Budapest.

KInCSES, Á.-TótH, G.-TÖMÖRI, M.-MichalKÓ, G. (2016): Identifying settlements involved in Hungary's transit traffic Regional Statistics 6 (1): 193-216. https://doi.org/10.15196/RS06110

KIss, J. P.-SzALKAI, G. (2018): Az ingázás mobilitási jellemzői a legutóbbi népszámlálások adatai alapján Terïleti Statiştika 58 (2): 177-199. https://doi.org/10.15196/TS580203

KoneckA-SzYdlowsKA, B.-TrócsÁnYI, A.-PIRISI, G. (2019): Urbanisation in a formal way? The different characteristics of the 'newest towns' in Poland and Hungary Regional Statistics 8 (2): 135-153. https://doi.org/10.15196/RS080202

KSH (2011): Elingázók aránya a foglalkoztatottakon belül http://webmap.lechnerkozpont.hu/webappbuilder/apps/foldgomb1708/ (downloaded: 11 August 2018).

KSH (2018): Magyarorsqág Helységnévtára https://www.ksh.hu/apps/hntr.main (downloaded: 11 August 2018).

LAKATOS, A.-MÁNDOKI, P. (2020): Sustainability analysis of competition in public transport systems: A comparative case study in Hungary and Finland Periodica Polytechnica Civil Engineering 64 (2): 545-556. https://doi.org/10.3311/PPci.14824

LAKATOS, A.-Tóth, J.-MÁNDOKI, P. (2020): Demand responsive transport service of 'dead-end villages' in interurban traffic Sustainability 12 (9): 3820. https://doi.org/10.3390/su12093820

LIMÃO, N.-VENABLES, A. J. (2001): Infrastructure, geographical disadvantage, transport costs, and trade The World Bank Economic Review 15 (3): 451-479.

MAOH, H. F.-KHAN, S. A.-ANDERSON, W. P. (2016): Truck movement across the CanadaUS border: The effects of $9 / 11$ and other factors. Journal of Transport Geography 53, 12-21. https://doi.org/10.1016/j.jtrangeo.2016.04.002

MÁRKUS, Á. (2018): Heterogén határhatások az Európai Unió egységes belső piacán - egy PPML és OLS-elemzés tanulságai Statisztikeai Szemle 96 (4): 375-402. https://doi.org/10.20311/stat2018.04.hu0375

MASSEY, F. J. (1951): The Kolmogorov-Smirnov Test for goodness of fit Journal of the American Statistical Association 46: 68-78. https://doi.org/10.1080/01621459.1951.10500769

MÁTYÁs, S.-SALLAI, J.-TihANYI, M.-VÁRI V. (2019): A rendőri elérhetőség és a bűnözés közötti összefüggések térbeli elemzése Területi Statisztika 59 (2): 152-163. https://doi.org/10.15196/TS590202

McCallum, J. (1995): National borders matter: Canada-U.S. Regional trade patterns The American Economic Review 85 (3): 615-623.

Regional Statistics, Vol. 10. No. 2. 2020:186-205; DOI: 10.15196/RS100208 
Miltiadou, M.-Bouhouras, E.-Basbas, S.-Mintsis, G.-Taxiltaris, C. (2017): Analysis of border crossings in South East Europe and measures for their improvement Transportation Research Procedia 25: 603-615. https://doi.org/10.1016/j.trpro.2017.05.445

MolnÁR, E.-DÉZsI, Gy.-LEnGYEL, I. M.-KoZMA, G. (2018): Vidéki nagyvárosaink gazdaságának összehasonlító elemzése Területi Statisztika 58 (6): 610-637. https://doi.org/10.15196/TS580604

NAGY, G. (2011): A gravitációs modell felhasználásának lehetőségei a várostérségek lehatárolásában Területi Statištika 51 (6): 656-673.

Niebuhr, A. (2008): The impact of EU enlargement on European border regions International Journal of Public Policy 3 (3):163-186

NovotnÝ, L.-PREGI, L. (2019): Visualization of migration using spatial interpolation method in Hungary and Slovakia Regional Statistics 8 (2): 184-188. https://doi.org/10.15196/RS080206

ODLYZKO, A. (2015): The forgotten discovery of gravity models and the inefficiency of early railway networks OEconomical 5: 157-192. https://doi.org/10.4000/oeconomia.1684

OkubO, T. (2004): The border effect in the Japanese market: A Gravity Model analysis Journal of the Japanese and International Economies 18 (1): 1-11. https://doi.org/10.1016/S0889-1583(03)00047-9

OpAsANON, S.-KITTHAMKESORN, S. (2016): Border crossing design in light of the ASEAN Economic Community: Simulation based approach Transport Policy 48: 1-12. https://doi.org/10.1016/j.tranpol.2016.02.009

PÁLÓCZI, G. (2016): A munkaerőpiaci ingázás vizsgálati lehetőségei komplex hálózatelemzéssel Területi Statisztikea 56 (2): 118-138. https://doi.org/10.15196/TS560202

PÁlóczi, G.-PÉnzes, J.-Hurbánek, P.-HAlás, M.-KlapkA, P. (2016): Attempts to delineate functional regions in Hungary based on commuting data Regional Statistics 6 (1): 23-41. https://doi.org/10.15196/RS06102

PARK, J.-KWON, C.-SON, M. (2014): Economic implications of the Canada-U.S. border bridges: Applying a binational local economic model for international freight movements. Research in Transportation Business \& Management 11, 123-133. https://doi.org/10.1016/j.rtbm.2014.06.003

PuPAVAC, D.-MARŠAnIĆ, R.-KRPAN, L. (2019): Elasticity of demand in urban traffic case study: City of Rijeka Periodica Polytechnica Transportation Engineering 48 (2): 173-179. https://doi.org/10.3311/PPtr.11750

ReChNitZER, J.-BERKES, J.-FiLeP, B. (2019): The most important city development initiatives of Hungary Regional Statistics 9 (2): 20-44. https://doi.org/10.15196/RS090204

SAIf, M. A.-ZEFreH, M. M.-TOROK, A. (2018): Public transport accessibility: A literature review Periodica Polytechnica Transportation Engineering 47 (1): 36-43. https://doi.org/10.3311/PPtr.12072

STEWART, J. Q. (1948): Demographic gravitation: Evidence and applications Sociometry 11 (1/2): 31-58. https://doi.org/10.2307/2785468

Regional Statistics, Vol. 10. No. 2. 2020:186-205; DOI: 10.15196/RS100208 
SZABÓ, Z.-SIPOS, T.-TÖRÖK, Á. (2017): Spatial econometric analysis of the Hungarian border crossings MATEC Web of Conferences 134: 00057. https://doi.org/10.1051/matecconf/201713400057

SZABÓ, Z.-TÖRÖK, Á. (2018a): Tranzitforgalmak Magyarországon: Egy térökonometriai elemzés Közlekedéstudományi Konferencia 8: 201-212.

SZABÓ, Z.-TÖRÖK, Á. (2018b): Magyarország határátkelőinek térökonometriai elemzése Közlekedéstudományi Szemle 68 (4): 46-60. https://doi.org/10.24228/KTSZ.2018.4.4

SZABÓ, Z.-TÖRÖK, Á.-SIPOS, T. (2019): Order of the cities: Usage as a transportation economic parameter Periodica Polytechnica Transportation Engineering (Online first paper) https://doi.org/10.3311/PPtr.13786

TAgAi, G.-BERnARD, J.-ŠIMON, M.-KoÓs, B. (2018): Two faces of peripherality: labour markets, poverty, and population dynamics in Hungary and Czechia Regional Statistics 8 (2): 19-45. https://doi.org/10.15196/RS080204

VARGA, L.-TÓTH, G.-NÉDA, Z. (2016): An improved radiation model and its applicability for understanding commuting patterns in Hungary Regional Statistics 6 (2): 27-38. https://doi.org/10.15196/RS06202

VArga, V.-Teveli-Horváth, D.-SAlamin, G. (2020): A fiatal, képzett lakosságot vonzó potenciál a Budapest körüli csapágyvárosokban Területi Statisztika 60 (2): 179-210. https://doi.org/10.15196/TS600204 